\title{
Goodwill under IFRS: Relevance and disclosures in an unfavorable environment
}

\author{
Diogenis Baboukardos* \\ Gunnar Rimmel \\ Jönköping International Business School
}

Accepted for publication in

\section{Accounting Forum}

Baboukardos, D. and Rimmel, G. (2014)

Goodwill under IFRS: Relevance and disclosures in an unfavorable environment. Accounting Forum, 38 (1). pp. 1-17.

* Corresponding author 


\title{
Goodwill under IFRS: Relevance and disclosures in an unfavorable environment
}

\begin{abstract}
The accounting treatment of purchased goodwill under IFRS has been severely criticized due to the extensive use of fair value accounting. The purpose of this study is to enrich the ongoing debate upon this issue by drawing attention to the market valuation implications of goodwill in a country outside the Anglo-Saxon accounting paradigm, where the application of fair value accounting has been seen as more problematic. The results indicate that, in the case of purchased goodwill, fair value accounting generates relevant accounting numbers but only in companies that comply highly with IFRS disclosure requirements.
\end{abstract}

Keywords: Goodwill, value relevance, fair value accounting, mandatory disclosures, IFRS, Greece

\author{
Abbreviations \\ ASE Athens Stock Exchange \\ FVA Fair Value Accounting \\ IFRS International Financial Reporting Standards \\ OLS Ordinary Least Squares
}

\section{Introduction}

The controversial nature of purchased goodwill has been puzzling accounting practitioners and scholars for more than a century. Since the end of the nineteenth century, accountants have been struggling to find the most appropriate accounting treatment for the pecuniary difference between the consideration transferred for acquiring a business and the acquiree's value (Cooper, 2007). Miller (1973) commends on this issue:

"The term 'goodwill' is necessary for the accountant because he attempts to disaggregate the purchase price for an organized whole only by isolation of elements which are classifiable according to traditional accounting procedure and which can be valued arbitrarily in terms of some historic costs or external market values" (Miller, 1973, p.285).

Even though little has changed regarding the recognition criteria for goodwill since Miller's commentary, the recent adoption of International Financial Reporting Standards (IFRS) by more than 120 countries has reignited the controversy regarding the measurement of purchased goodwill due to the extensive use of fair value accounting (FVA). FVA is said to have desirable but also questionable attributes. On the one hand, fair value is considered a superior economic measure in comparison with historical cost, but on the other hand, it may lead to valuation failures, mainly in cases in which 'mark to model' estimations are employed (Ball, 2006; Franklin \& Carletti, 2008; Penman, 2007). Goodwill accounting is heavily influenced by FVA both at goodwill's initial recognition and measurement under IFRS 3 as well as at its subsequent annual impairment test under IAS 36. As a consequence, purchased goodwill is found in the center of the criticism for FVA (Ramanna, 2008; Sevin \& Schroeder, 2005; Wines et al. 2007). For instance, Wines et al. (2007) criticize the new accounting treatment of goodwill as highly subjective and with potential negative implications for financial reporting. In addition, Beisland (2013) argues that if fair values for certain assets are not easily accessible, then it is very possible that companies' market valuation will be hindered (and not 
facilitated) by FVA. Similarly, Ball (2006) notes that in countries that depart from the economic and legal environment of the so-called Anglo-Saxon countries, there is a higher probability of problems with 'mark to model' estimates occurring due to these countries' unfavorable institutional environments and accounting traditions. In such settings, the relevance of accounting numbers influenced by FVA is questionable and worthy of examination.

Whether these concerns are valid remains an open empirical question, as there is no clear evidence of the market valuation implications of assets that are heavily influenced by FVA under IFRS, especially in unfavorable environments for the application of the new Standards. With regard to goodwill, its market valuation implications have mainly been examined in Anglo-Saxon accounting settings, where local accounting standards present many similarities to IFRS. However, there is no clear evidence concerning this issue in unfavorable (for the implementation of IFRS) environments. This study attempts to shed some light upon this empirical issue. Specifically, it examines the value relevance of purchased goodwill under IFRS in a number of companies listed on the Athens Stock Exchange (ASE). Greece can be classified as an unfavorable environment because it is a code-law Continental European country with a stakeholder-oriented and taxation-driven national accounting system (Ballas et al., 1998; Nobes, 2008). In addition, because Greece is a low-trust society, its accounting environment is highly formalistic; hence, the use of FVA is limited in favor of historical cost accounting. Thus, the consequences of the application of the new Standards, especially those that are heavily influenced by FVA, on the market valuation of accounting numbers are questionable.

Another important consequence of the highly formalistic accounting environment in Greece is the absence of extensive supplementary disclosure requirements. The local accounting standards do not leave much space for management discretion; thus, there is no need for mandating detailed disclosures. The mandatory implementation of IFRS by all listed companies in 2005, however, has vastly changed the reporting landscape. The new Standards leave much more space for management discretion (especially where FVA is applied); hence, there is a need for the justification of management decisions. This need is claimed to be covered by the mandating of voluminous disclosures by IFRS.

Despite the allegedly important role of mandatory disclosures, there is a lack of empirical studies on their valuation implications. This study corresponds to the calls for further research on the field of mandatory disclosures (Leuz \& Wysocki, 2008; Schipper, 2007; Zéghal \& Maaloul, 2011) [12,13,14] by examining whether companies' decisions to comply to a greater or lesser extent with the IFRS disclosure requirements for goodwill bears any impact on the value relevance of their purchased goodwill.

Some European evidence shows that the value relevance of net income is significantly higher for companies that comply highly with IFRS disclosure requirements than for those that do not (Paananen, 2008; Tsalavoutas \& Dionysiou, 2013). On the contrary, the same studies find that the value relevance of balance sheet items at an aggregated level (that is, the book value of shareholders' equity) does not differ between companies that comply with IFRS disclosure requirements to a greater extent and those that comply to a lesser extent.

Nevertheless, there are reasons to believe that the market valuation implications of specific balance sheet items that are heavily influenced by FVA might differ. The main reason is as follows. For accounting items heavily influenced by FVA, explanatory disclosures are of high importance because the accounting treatment of these items does not follow detailed rules but is strongly based on managerial decisions. These decisions are primarily related to assumptions, forecasts and projections about the future and need to be justified. The insufficient justification of the management's decisions may lead to accounting numbers of low reliability and therefore low value relevance. Otherwise, the extensive disclosure requirements of IFRS seem to have no impact on accounting items' valuation implications, allowing their usefulness to be questioned.

The present study attempts to enrich our understanding of mandatory disclosures focusing on IFRS disclosures for goodwill. Specifically, using two different approaches for measuring the level of 
compliance with IFRS mandatory disclosure requirements for goodwill, this study examines whether goodwill's value relevance differs between companies with relatively high and low levels of compliance.

The remainder of this study is structured as follows. The next section describes the Greek accounting environment and justifies why it can be characterized as unfavorable for the application of IFRS. Subsequently, prior studies are discussed to develop the tested hypotheses. The research design is then illustrated, and the company selection procedure is outlined. The data are described and the empirical analyses are presented in the next section. Finally, conclusions are drawn.

\section{Implementing IFRS in an unfavorable environment}

Greece is classified as a code-law Continental European country with a stakeholder-oriented and taxation-driven national accounting system (Ballas et al., 1998; Nobes, 2008; Nobes 2011). Similar to most Continental European domestic accounting standards, under Greek accounting standards, the use of FVA is limited in favor of historical cost accounting. Hence, it can be characterized as an unfavorable environment for the implementation of IFRS and the application of FVA in particular. Greece's domestic accounting standards are mainly influenced by the French accounting system and the European Union's legislation (namely, the Fourth and Seventh EU Directives), which differ substantially from IFRS (Ding et al., 2007). Specifically, Bae et al. (2008) provide evidence that among the 15 oldest member states of the European Union, Greece presents the second largest difference between its national accounting standards and IFRS.

One of the most characteristic examples of the differences between IFRS and Greek accounting standards can be found in the accounting treatment of purchased goodwill. Accounting for goodwill under IFRS is heavily influenced by FVA both at the initial recognition and measurement of goodwill under IFRS 3 and at its subsequent impairment test under IAS 36. The only acceptable method for the accounting treatment of business combinations recognized by IFRS 3 is the so-called acquisition (or purchase) method, which, unlike the pooling of interest method, requires the fair valuation of the acquirer's transferred consideration (including other previously held interests) as well as that of the acquiree's identifiable net assets. If the value of the transferred consideration is larger than that of the identifiable net assets, the difference is recognized in the new entity's statement of financial position as goodwill and is subject to an (at least) annual impairment test according to IAS 36. Otherwise, the difference is recognized as a bargain purchase in the statement of comprehensive income.

Greek accounting regulation recognizes the acquisition method as the primary method for business combinations; however, it requires the application of pooling of interest method under specific conditions. In particular, Codified Companies' Law 2190/20 (par. 68-80) identifies two basic methods for achieving a business combination: mergers and acquisitions. A merger can be realized by either consolidating the merging entities into a new entity or retaining one of the merging entities, which eventually 'absorbs' the assets and liabilities of the 'absorbed' entities. Moreover, a business combination is identified as an acquisition when the acquiring entity purchases the whole of the target entity or when the acquiring entity acts as a holding company by purchasing sufficient stock to gain control of the target entity. In all of these cases, the acquisition method should be employed whilst the valuation of combined entities' assets and liabilities is carried out by a special committee of external, independent valuators convened by the local prefecture authorities. If the value of the cost of the combination is higher than the net value of the assets resulting from the committee's valuation, the difference is recognized as goodwill.

Unlike IFRS, under Greek accounting regulation, goodwill shall be amortized in a period of no more than five years. Table 1 compares the valuation methods employed in business combinations accounted by the acquisition method under IFRS and Greek accounting regulation. Whereas the domination of fair values is prominent under IFRS, the approach adopted under Greek regulation is by far more prudent, as it permits the valuation of most balance sheet items at market values so long 
as the market values are lower than the respective historical costs. An important exception to this rule is the valuation method of tangible assets, which, similar to IFRS 3, calls for recognition of tangible assets at current values.

Finally, it should be stressed that when a business combination is realized under Law 2166/93 (and not under the basic Companies' Law 2190/20), the combined entities are required to apply the pooling of interest method and hence recognize their assets and liabilities at book values. Consequently, under this law, it is not feasible to recognize goodwill. It is worth mentioning that Law 2166/93 is another example of the substantial influence of tax regulation on financial reporting in Greece, as the motivation for the application of the pooling of interest method requirement is the exceptionally favorable tax benefits offered by the law.

[Insert Table 1 about here]

In addition to the origins of Greek accounting standards, another important reason for classifying Greece as an unfavorable environment for the implementation of IFRS is the absence of trust between the Greek state and its citizens as well as amongst citizens (Ballas et al., 1998). The absence of trust has been diachronically playing a key role in the development of detailed accounting rules, which virtually hinder companies to report their fundamentals in a true and fair view for the sake of formalism:

"It (A/N: Formalism) provides reporting entities with ground rules on what is 'acceptable' in a manner which can be communicated easily without having to document why a specific alternative (disclosure, valuation rules, etc.) is preferred" (Ballas et al., 1998, p. 279).

Under Greek accounting standards, companies have to follow very specific rules that leave little space for management discretion. As a corollary, Greek regulation mandates far fewer disclosures than IFRS because companies do not have to clarify how they come up with their figures; the rules are detailed and unquestionable, and the emphasis is placed on providing hard figures (Ballas, 1994).

In 2005, all listed companies on the ASE had to abandon the established unwritten 'rule of formality' and adopt principle-based accounting standards that call for extensive use of FVA where the role of management discretion is crucial. For that reason, and unlike Greek accounting rules, IFRS calls for voluminous disclosures that justify management's decisions. Nevertheless, it is largely questionable whether the inherent subjectivity of FVA has been welcome in unfavorable environments such as Greece. Ball (2006), discussing the implementation of IFRS in Continental European countries, notes that "It remains to be seen if managers, auditors, regulators and other monitors outside of the common-law countries will be persuaded by IFRS adoption that it is in their interests to radically change their behavior" (Ball, 2006, p. 17). Preliminary evidence from Greece is not very encouraging. Karampinis and Hevas (2011) compare earnings' value relevance and conditional conservatism between the last three years of the application of Greek accounting standards and the first three years of IFRS implementation in ASE and find insufficient evidence of improvements in these accounting properties after the mandatory adoption of IFRS. Hence, it can be inferred that Greece remains an unfavorable environment for the implementation of IFRS.

\section{Literature review and hypothesis development}

Several studies examine the value relevance of purchased goodwill (Eckstein, 2004; El-Tawy \& Tollington, 2013). Nevertheless, almost all of these studies investigate the phenomenon in AngloSaxon accounting settings (mainly in Australia and the US). Specifically, Chauvin and Hirschey (1994), Jennings et al. (1996) and McCarthy and Schneider (1995) find a strong positive association between goodwill and US firms' market value. Bugeja and Gallery (2006), Dahmash et al. (2009) 
and Ritter and Wells (2006) conclude that Australian firms' market value is influenced positively by goodwill. Furthermore, Chalmers et al. (2008) find that, overall, goodwill's value relevance was enhanced after the adoption of Australian IFRS equivalents in 2005 relative to Australian GAAP. Ojala (2007) finds that under Finnish GAAP, goodwill was value relevant, especially when companies applied a short amortization period. Jifri and Citron (2009) examine whether goodwill had similar information value when it was disclosed in the supplementary notes and when it was recognized in the UK firm's financial statements under UK FRS. They find that both recognized goodwill and disclosures about goodwill were value relevant.

The almost total absence of studies outside the Anglo-Saxon accounting paradigm raises the question of whether the results of these studies are applicable to countries with different accounting paradigms, especially after the mandatory adoption of IFRS by these countries.

With reference to Greece, listed companies on the ASE declare that the adoption of IFRS improved the relevance of their financial statements (Ballas et al., 2010). However, the empirical evidence regarding this issue is mixed. Iatridis and Rouvolis (2010) find that the book value of equity and net profit of companies listed on the ASE were more value relevant in the first two years of mandatory implementation of IFRS than in 2004, the last year of the application of Greek accounting standards. On the contrary, Karampinis and Hevas (2011) conclude that IFRS adoption only has minimal effects on accounting numbers' value relevance.

Greece is an interesting setting for the examination of purchased goodwill's value relevance. As discussed in the previous section, Greece is regarded as an unfavorable environment for the application of IFRS due to its Continental European accounting tradition as well as its companies' formalistic behavior (Ballas et al., 1998). In addition, IFRS calls for an accounting treatment of goodwill that has raised many objections (Ramanna, 2008; Sevin \& Schroeder, 2005; Wines et al. 2007). For example, Wines et al. (2007) stress that the new accounting treatment of goodwill "is fraught with subjectivity and ambiguity for financial report preparers and auditors, and potentially has serious impacts on financial reports" (Wines et al., 2007, p. 863). Taking into account that these objections are primarily derived from countries with long traditions in accounting systems similar to IFRS (i.e., the so-called Anglo-Saxon, common-law countries), it can be assumed that participants in markets with the characteristics of the Greek market may have even greater concerns about goodwill and similar accounting numbers.

Ball (2006) raises this issue, noting that in countries that depart from the economic and legal environment of the 'G4+1' common-law countries (i.e., Australia, Canada, New Zealand, the UK and the US) the implementation of IFRS fair value accounting will lead to difficulties with illiquidity, wide spreads and subjectivity in 'mark to model' estimates of fair value. These problems may affect the relevance of accounting information. Hence, it is useful to examine whether the 'fair valuation' of goodwill under IFRS in an unfavorable environment for the application of IFRS leads to relevant information. The first hypothesis this study examines is

\section{$\mathrm{H}_{1}$ : Purchased goodwill under IFRS is value relevant.}

Additionally, the present study addresses the call for further research in the field of mandatory disclosures (Leuz \& Wysocki, 2008; Schipper, 2007). Despite the allegedly important role of mandatory disclosures, there is a lack of studies on their valuation implications. Schipper (2007) notes,

\footnotetext{
"Despite their abundance, required disclosures are not well understood: we lack a comprehensive theory of mandatory disclosures; many questions remain as to how preparers, auditors, and users of financial reports view disclosures..." (Schipper, 2007, p. 301)
} 
Hassan et al. (2006) argue that one of the reasons that little attention has been given to mandatory disclosures is that most studies are conducted in developed markets with strong enforcement mechanisms, which ensure a high level of compliance with mandatory disclosures by almost all companies. Nevertheless, there is evidence that the excessive disclosure requirements mandated by IFRS are not fully followed in even some of the most developed markets.

The 2009 report for the European Enforcement Coordination Sessions (EECS) of the then Committee of European Securities Regulators ${ }^{1}$ (CESR) notes that although the overall quality of IFRS reporting in Europe had improved by 2009, "financial reports varied considerably in the extent to which issuers disclosed clearly, consistently and sufficiently comprehensively, the main judgments made in the preparation of financial statements" (CESR, 2009, pp. 11-12). Two of the key issues discussed repeatedly in EECSs during 2009 were disclosures for the impairment of non-financial assets and business combinations, both of which are closely related to goodwill. Moreover, the Financial Reporting Council (2008) assesses goodwill impairment disclosures in 32 of the top 350 UK listed companies' reports for the 2007 fiscal year and characterizes over half of them as rather uninformative. Low levels of compliance with disclosure requirements about goodwill are also detected in Hungarian companies by Fekete et al. (2008), who find that the average Hungarian company disclosed 55\% of the applicable disclosure items of IFRS 3 in 2006. Moreover, Paananen (2008), using a 13-item index related to the fair value accounting of goodwill, finds that UK-, France and Germany-based companies disclosed on average $34 \%, 29 \%$ and $23 \%$ of the items, respectively, for the year 2005 .

Regarding Greece, Tsalavoutas and Dionysiou (2013) find that in 2005, companies listed on the ASE complied with $70 \%$ and $49 \%$ of applicable disclosure requirements of IFRS 3 and IAS 36, respectively, on average. In addition, Ballas and Tzovas (2010) find a similar level of compliance with disclosure requirements about goodwill in a small sample of Greek listed companies for 2006.

The non-compliance with mandatory disclosure requirements may be a negative signal for the market. For instance, Sengupta (1998) argues that investors try to assess a firm's default risk based on all available information before lending money to the firm. A factor very likely to be included in their risk assessment is the probability that the firm withholds negative information. The larger this probability is, the higher the risk premium investors charge the firm and consequently the lower the market value of the firm. Thus, it can be argued that in a mandatory disclosures context, even less sophisticated investors can easily locate any management attempt for concealing information, as these disclosures are specified by accounting standards (Healy \& Palepu, 2001). For instance, in the case of goodwill impairment testing, if the issuer bases the computation of a cash-generating unit's recoverable amount on the value in use, they should disclose information about the assumptions made and the growth rate used for the cash flow projections, explain how the values assigned to each assumption have been determined, justify the period used for the cash flow projections and disclose the discount rates applied (see Appendix A disclosure items 6-10). To the extent that this information justifies whether goodwill should be impaired, it enables investors to better interpret the effects of this accounting number on the future performance of the company (Kang \& Pang, 2005) or to confirm their previous evaluations.

To date, there is little empirical evidence on whether companies' compliance behavior with IFRS mandatory disclosure requirements affects the value relevance of accounting numbers. The only studies examining this issue are those of Paananen (2008) and Tsalavoutas and Dionysiou (2013). Both studies attempt to examine whether different levels of disclosure are associated with different levels in the value relevance of income and of book value of equity. The findings of both studies indicate that there is a significant difference in the value relevance of income but no difference in the value relevance of book value of equity.

\footnotetext{
${ }^{1}$ In 2001, the Committee of European Securities Regulators (CESR) was established as an independent committee of European Securities regulators. In the beginning of 2011, CESR was replaced by the European Securities and Markets Authority (ESMA), which is part of the European System of Financial Supervision.
} 
Specifically, the study of Paananen (2008), despite examining disclosures related to goodwill, does not attempt to associate them with goodwill's value relevance. Moreover, although the study of Tsalavoutas and Dionysiou (2013) examines the disclosures of almost all IFRS, it does not provide insights into the relationship between the volume of specific standards' disclosures and the value relevance of specific accounting numbers, e.g., IFRS 3 and IAS 36 disclosures with goodwill. In addition, both studies use samples from the first year of the mandatory implementation of IFRS, and there is evidence that not all companies were well prepared for the transition (Ballas et al., 2010; Jermakowicz \& Gornik-Tomaszewski, 2006). Thus, the companies included in their samples might be substantially heterogeneous regarding their level of preparation for applying IFRS.

The present study attempts to enrich our understanding of mandatory disclosures by focusing on goodwill disclosures. Specifically, it investigates whether there is a systematic difference in goodwill's valuation effects between companies with relatively high and relatively low levels of compliance with IFRS mandatory disclosure requirements for goodwill. Although prior studies (Paananen, 2008; Tsalavoutas \& Dionysiou, 2013) have shown that the valuation of balance sheet items at an aggregated level (that is, the book value of equity) does not differ between companies that comply with IFRS disclosure requirements to greater and lesser extents, there are reasons to believe that specific balance sheet items that are heavily influenced by FVA might have a different attitude due to the particular importance of these items' disclosures. Among accounting items heavily influenced by FVA, explanatory disclosures are of high importance because the accounting treatment of these items does not follow detailed rules, being based to a large extent on managerial decisions, which have to be justified. An insufficient justification of the assumptions, forecasts and projections made by the management shall lead to accounting numbers of low reliability and hence low relevance. Otherwise, the extensive disclosure requirements of IFRS seem to have no impact on accounting items' valuation implications, leading to the questioning of their usefulness.

With regard to the focus of this study, IFRS 3 and IAS 36 mandate voluminous disclosures to provide users with sufficient information to assess the objectivity of the management's assumptions and valuations. In such a mandatory disclosures setting, investors have a 'benchmark' of extensive disclosures that they expect to find in companies' annual reports. Hence, it is interesting to examine whether this 'benchmark' affects the relevance of the accounting item under consideration, in this case, goodwill. Specifically, the second hypothesis this study examines is

$\boldsymbol{H}_{2}$ : There is a systematic difference in goodwill's value relevance between companies with relatively high and relatively low levels of compliance with IFRS mandatory disclosure requirements for goodwill.

\section{Research design}

\subsection{Empirical models}

This study tests two hypotheses related to the balance sheet item of purchased goodwill: whether goodwill recognized in financial statements of companies listed on the ASE is value relevant and whether there is a systematic difference in goodwill's valuation effects between companies with relatively high and relatively low levels of compliance with IFRS mandatory disclosure requirements for goodwill. Following a well-established branch of value relevance literature (see, for example, Aboody \& Lev, 1998; Beisland, 2013; Bugeja \& Gallery, 2006; Jifri \& Citron, 2009; Kang \& Pang, 2005; Ritter \& Wells, 2006), an adaptation of Ohlson (1995) model is employed to test the hypotheses of this study, which associates a firm's market value of equity (MV) with its book value of equity (BV) and net income before taxes (NIBT):

$$
M V_{i}=\alpha_{0}+a_{1} B V_{i}+a_{2} N I B T_{i}+\varepsilon_{i}
$$


More specifically, its deflated (by the number of common shares outstanding) version is used:

$$
P R_{i}=\alpha_{0}+a_{1} B V S_{i}+a_{2} E P S_{i}+\varepsilon_{i}
$$

where PR is the market value of equity per share four months after company i's fiscal year-end, BVS is the book value of equity per share recognized on company i's annual balance sheet, EPS is the net income before taxes per share recognized on company i's annual income statement and $\varepsilon$ is the error term. The use of market values four months after the end of the fiscal year ensures that the accounting information is reflected in the market values, as Greek legislation requires that all listed companies release their annual reports no later than three months after the end of their fiscal year.

To mitigate size effects and heteroscedasticity problems, which occur frequently in cross-sectional level-based designs, the initial model 1 as well as its expansions, models 2 and 3 (discussed later in this text), are estimated on a per share basis, scaled by the number of common shares outstanding four months after the company's fiscal year-end. Barth and Clinch (2009) compare six alternative estimation models specifications of Ohlson (1995) model and find that using per share specifications better mitigates such problems because it results in more consistent and less biased estimations of the coefficients' p-values and regression explanatory power. In addition, observations with high values of Cook's distance statistic ${ }^{2}$ are identified as highly influential and are therefore eliminated. Finally, White's t-statistic adjustments are used.

Moreover, prior studies have evidenced significant differences between the earnings coefficients of loss- and profit-making companies (Hayn, 1995; Joos \& Plesko, 2005). To control for such differences, a binary variable LOSS is used, which equals one if the company is loss-making and zero otherwise. Finally, the model is augmented by the dummy variable IND, which controls for industry effects. Specifically, IND equals one if the company is manufacturing and zero otherwise. Hence, the basic model is the following:

$$
P R_{i}=\alpha_{0}+a_{1} B V S_{i}+a_{2} E_{P S}+\text { Controls }_{i}+\varepsilon_{i}
$$

Model 1 is the basic aggregated model. Model 2 is obtained by decomposing BVS across the book value of equity excluding goodwill per share (BV_GWS) and book value of goodwill per share (GWS). Similar to Bugeja and Gallery (2006), Jifri and Citron (2009) and Ritter and Wells (2006), model 2 is used for the examination of purchased goodwill's value relevance:

$$
P R_{i}=\alpha_{0}+a_{1} B V_{-} G W S_{i}+a_{2} G W S_{i}+a_{3} E P S_{i}+\text { Controls }_{i}+\varepsilon_{i}
$$

Value relevance studies examine how well the accounting number(s) of interest are reflected in companies' equity market values (Barth et al., 2001). Because the main scope of the first hypothesis is the examination of goodwill's value relevance, coefficient $\alpha_{2}$ is of particular interest. If coefficient $\alpha_{2}$ is found to be positive and statistically significant (different from zero), then it can be inferred that goodwill "reflects information relevant to investors in valuing the firm and is measured reliably enough to be reflected in share prices" (Barth et al., 2001, p. 80).

Regarding the second hypothesis, to investigate whether there is a systematic difference in purchased goodwill's valuation effects between companies with relatively high and relatively low levels of

\footnotetext{
${ }^{2}$ Observations with Cook's distance statistic greater than $4 / n$, where $n$ is the number of observations.
} 
compliance with IFRS disclosure requirements for goodwill, the binary variable DLC is incorporated in model 2. DLC results from the level of compliance with IFRS disclosure requirements for goodwill (hereafter LC), which is discussed in the next section. DLC equals one if the LC is greater than or equal to the median of the sample's LC and zero otherwise. The new model 3 is the following:

$$
P R_{i}=\alpha_{0}+a_{1} B V_{-} G W S_{i}+a_{2} G W S_{i}+a_{3} E P S_{i}+a_{4} D L C_{i}+a_{5} G W S_{i} \times D L C_{i}+\text { Controls }_{i}+\varepsilon_{i}
$$

In this case, the interest is focused on the coefficient $\alpha_{5}$ of the interaction variable. If $\alpha_{5}$ is statistically significant and positive, then it can be inferred that the value relevance of goodwill under IFRS is higher in companies with a relatively high level of compliance than in companies with a relatively low level of compliance with IFRS disclosure requirements for goodwill.

\subsection{Level of compliance ratio}

As discussed in the previous section, testing the second hypothesis requires the computation of companies' levels of compliance with IFRS disclosure requirements for goodwill. Hence, a disclosure index is constructed (see Appendix A) in which all of the IFRS 3 disclosure requirements (38 disclosure items) and the requirements of IAS 36 related to goodwill (20 disclosure items) are included $^{3}$. The index is based on Deloitte's IFRS - Presentation and Disclosure Checklist (Deloitte, 2009). Prior studies have followed a similar pattern using indices constructed, for instance, by S\&P (Othman \& Zeghal, 2010), Ernst and Young (Glaum \& Street, 2003) or the Egyptian Capital Market Authority (Hassan et al., 2006). In addition, to ensure its thoroughness, the index is compared with similar checklists for the other three Big-4 accounting firms (Ernst \& Young, 2009; KPMG, 2009; Pricewaterhouse, 2009).

The use of an index enables the quantification of the level of compliance through a ratio (LC) that takes values from zero (no compliance) to one (full compliance). To calculate the LC, two approaches are employed to ensure that the results are not driven by the chosen approach. First, the so-called unweighted approach is employed (Cooke, 1989; Glaum \& Street, 2003; Hassan et al., 2006; Jahangir et al., 2004; Othman \& Zeghal, 2010). According to this approach, if a required item is found to be disclosed, it is scored as ' 1 '. If not, it is scored as ' 0 ', and if the item is not applicable, it is characterized as 'NA'. The LC of each company is calculated as the ratio of the total items disclosed to the total number of applicable disclosure items. This method treats each disclosure item equally and thus assumes that users place the same 'weight' on each item or, in other words, that each item is of equal importance to the users. Cooke (1989), arguing in favor of the unweighted approach, notes that "An approach which tried to encapsulate the subjective weights of a multitude of user groups would be unwieldy and probably futile" (Cooke, 1989, p. 182).

Nevertheless, when multiple accounting standards are examined, the unweighted approach has a disadvantage: the more items are mandated by a standard, the greater the impact of this standard on the level of compliance (Tsalavoutas et al., 2010). The present study examines companies' levels of compliance using two standards that differ substantially in the number of disclosure items they mandate (38 for IFRS 3 and 20 for IAS 36). Thus, to ensure that the results of the study are not affected by the measurement method, a second, weighted approach is employed. This method treats each standard and not each disclosure item equally (Street \& Gray, 2002; Tsalavoutas \& Dionysiou, 2013). A separate compliance ratio per standard is calculated following the unweighted approach described previously, and the sum of the compliance ratios per standard is then divided by the number of applicable standards examined. Finally, to ensure that the examined companies are not penalized

\footnotetext{
${ }^{3}$ As discussed in the next section, the sample is comprised of companies found to have purchased goodwill recognized in their 2008 annual reports. It should be mentioned that in 2008, none of these companies voluntarily adopted the thennew amendments of the standards mandated by January $1^{\text {st }}, 2009$. Thus, the same requirements apply to all companies.
} 
for noncompliance with disclosures that are not applicable, the complete annual report of every company is reviewed.

\subsection{Sample selection and data sources}

For the empirical tests, data from the 2008 fiscal year are used. According to the daily official stocklist of the ASE, 283 companies were actively traded in the market on April $30^{\text {th }}, 2009^{4}$. A detailed search of the 2008 annual reports of these companies revealed that 95 have purchased goodwill recognized on their financial statements. Of these 95 companies, 10 belong to the banking and financial services sectors and are therefore excluded due to the different nature of their assets and liabilities and the different regulatory requirements applied to them. These differences may have a substantial impact on the relationship between accounting numbers and market values (Ahmed et al., 2000; Dahmash et al., 2009). In addition, under Greek legislation, a firm's fiscal year shall end on either December $31^{\text {st }}$ or June $30^{\text {th }}$. Two of the companies have fiscal years ending on June $30^{\text {th }}$ and are eliminated to ensure that all companies are at a similar stage in the process of financial statement preparation (Bugeja \& Gallery, 2006; Jennings, et al., 1996). Two more companies with negative book values of equity are excluded to enhance the inferential quality (Ahmed et al., 2000) and reduce the noise (Bugeja \& Gallery, 2006) of the empirical tests. Finally, five companies are identified by Cook's distance statistic ${ }^{5}$ as highly influential observations and are thus eliminated. The final number of companies included in the initial analysis is 76 (Table 2). Appendix B lists the 76 companies and their respective industry classifications.

[Insert Table 2 about here]

Regarding the sources of the data utilized in this study, the accounting data (book value of equity, goodwill and net income before taxes) result from hand-collection during the review of companies' 2008 annual reports. For the industry binary variable, the ASE classification is adopted. Finally, the market value of the equity and the number of common shares outstanding four months after the end of the companies' fiscal year (that is, April 30 $30^{\text {th }}$ 2009) are retrieved from Thomson Reuters Datastream database.

\section{Findings}

\subsection{The level of compliance descriptives}

Table 3 provides basic summary statistics for the level of compliance per standard (IFRS 3 and IAS 36) and per measurement approach (LC_u for unweighted and LC_w for weighted). One company was found to not be required to comply with any of the IAS 36 disclosure requirements; therefore, descriptive statistics for the level of compliance with IAS 36 are provided for the remaining 75 observations. A first striking finding is that although companies comply highly with IFRS 3, they present the opposite behavior towards IAS 36 requirements. Specifically, the mean level of compliance with IFRS 3 requirements is 0.82 , and the median is 1.00 , showing that over half of the companies (41 companies) fully comply with IFRS 3. On the other hand, the mean level of compliance with IAS 36 requirements is only 0.29 , with standard deviation 0.35 and median 0.14 . In fact, 30 companies were found to exhibit no compliance with IAS 36 disclosure requirements.

\footnotetext{
${ }^{4}$ Greek accounting regulation dictates that companies' fiscal years shall end on either December $31^{\text {st }}$ or June $30^{\text {th }}$, whereas in practice, almost all companies listed on the ASE have fiscal year-ends on December $31^{\text {st }}$. Because the dependent variable of the empirical models employed is the market value of equity four months after the company's fiscal year-end, the sample companies must be active on April $30^{\text {th }}$ to be included.

${ }^{5}$ Observations with Cook's distance greater than $4 / n$, where $n$ is the number of observations, are excluded.
} 
[Insert Table 3 about here]

Regarding the total level of compliance, the average company complies with approximately half of the disclosure requirements. Specifically, under the unweighted approach, the mean of LC_u is 0.49, whereas under the weighted approach, the mean of LC_w is 0.56. Similarly, the medians of LC_u and LC_w are 0.44 and 0.51 , respectively. It should be stressed that the difference is statistically significant (Wilcoxon signed-rank $\operatorname{test}^{6} \mathrm{z}=-3.508, \mathrm{p}=0.001$ ). This significant difference further validates potential concerns about employing a single method for measuring the level of compliance. This finding is indicative that 18 companies ( $24 \%$ of the sample) are classified in different compliance groups (high/low) under the two different measurement approaches. Hence, the employment of such significantly different measuring approaches ensures that the findings are not driven by the measurement method.

\subsection{Data description and univariate analysis}

Table 4 presents companies' distribution per level of compliance and industry. Of the 18 ASE industries, 14 are presented in the sample. It is worth mentioning that companies from three additional sectors are found to have purchased goodwill recognized on their financial statements, but they are eliminated for reasons discussed in section 4.3. Although almost every ASE industry is represented in the sample, the distribution of companies per industry is largely uneven. More than half of the companies (56\%) belong to four industries (construction and materials, industrial goods and services, food and beverage, technology). An interesting, albeit expected, finding is that three of these industries can be characterized as intangible-intensive industries. Specifically, Collins et al. (1997) identify seven intangible-intensive industries (plastic and synthetic materials; drugs; computer and office equipment; electronic components and accessories; communications; business services; engineering, accounting, $R \& D$ and management related services), which coincide with three of the ASE sectors mentioned above. Overall, 42 companies (55\%) can be identified as belonging to an intangible-intensive industry. With respect to the partitioning of companies into high- and low-LC groups, the food and beverage industry presents a large discrepancy between the number of companies with high and low levels of compliance, with the latter far exceeding the former. The industrial goods and services industry presents the opposite trend, as most companies comply highly with the examined disclosure requirements.

\section{[Insert Table 4 about here]}

Table 5, Panel A provides basic summary statistics for the variables utilized in the multivariate analysis for the full sample as well as per compliance group under both measurement approaches. All accounting/financial variables are presented on a per share basis. A non-parametric Mann-Whitney test $^{7}$ reveals that under the unweighted approach, the average company that belongs to the highcompliance group has a significantly larger market value per share, book value per share and goodwill per share than the average company in the low-compliance group. However, this is not the case under the weighted approach, where the test reveals no significant difference in any of the variables. Regarding the binary variables, it is worth mentioning that $39 \%$ of the companies are in the manufacturing industry and that a quarter of the examined companies reported losses in 2008.

\footnotetext{
${ }^{6}$ A non-parametric test is chosen due to data deviation from normality

${ }^{7}$ A non-parametric test is chosen due to data deviation from normality.
} 
To obtain a more informed understanding of the sample, Table 5, Panel B provides supplementary descriptives of the sample companies' purchased goodwill as a proportion of their total assets and net assets. These data are not utilized in further statistical analysis but are useful for drawing inferences regarding companies' characteristics in relation to their level of compliance. Specifically, the aim of this analysis is to provide some evidence on whether companies that differ in terms of their level of compliance with goodwill disclosure requirements also differ in terms of the magnitude of purchased goodwill they accumulate on their balance sheets. A large amount of accumulated goodwill might present an additional value at risk in the case of impairment recognition (Haslam et al., 2013). Thus, it is reasonable to assume that the level of compliance would be higher in companies where goodwill constitutes a large part of their assets than in those with a smaller goodwill-to-assets ratio.

On average, goodwill constitutes a considerable part of companies' balance sheets. Specifically, $6 \%$ of companies' total assets and $23 \%$ of their net assets is purchased goodwill. In addition, it is worth mentioning that purchased goodwill represents a considerable amount of companies' balance sheets regardless of their classification as low- or high-compliance companies. Under the unweighted approach, the average low-compliance company has a goodwill-to-total-assets ratio of 5\% and a goodwill-to-net-assets ratio of $18 \%$, whereas the respective ratios for the average high-compliance company are $8 \%$ and $29 \%$, respectively. Under the weighted approach, the ratios are the same except for that of goodwill to net assets for low-compliance companies, which is $17 \%$. A Mann-Whitney test reveals that, under the unweighted approach, low- and high-compliance companies differ significantly in regard to the goodwill to total assets ratio. However, no significant difference is found for the same ratio under the weighted approach. Furthermore, regardless the measurement approach, the goodwill-to-net-assets ratio between the two groups does not present any significant difference. Based on the above findings, it can be inferred that companies that differ in terms of their level of compliance with goodwill do not differ in terms of the magnitude of purchased goodwill they accumulate on their balance sheets, at least when the level of compliance is measured under the weighted approach.

[Insert Table 6 about here]

Finally, Table 6 reports the Spearman and Pearson correlation coefficients for all of the variables utilized in the analysis. The correlations among variables are within the conventional levels (less than 0.80), indicating the absence of multicollinearity problems (Gujarati, 1995). In one case, the correlation coefficients are found to be higher than the threshold of 0.80 (BVS and BV_GWS), but this has no impact on the analysis because these two variables are not used in the same regressions. Moreover, the GWS variable is positively correlated with the dependent variable, which can be interpreted as a preliminary indication on a univariate basis that purchased goodwill is value relevant.

\subsection{Multivariate analysis}

Table 7 shows the estimated coefficients of the multiple ordinary least squares (hereafter OLS) regressions for the three models. Model 1 is the basic aggregated model, which tests the value relevance of book value of equity per share (BVS) and net income before taxes per share (EPS). The main model for testing the first hypothesis is model 2, in which BVS is decomposed across book value of equity excluding goodwill per share (BV_GWS) and goodwill per share (GWS). The results for model 1 show that the book value of equity (BVS) and net income before taxes (EPS) are highly associated with companies' market value (PR). In particular, the model 1 regression coefficients are 
0.596 for BVS and 2.957 for EPS (both statistically significant at the $1 \%$ level). Regarding model 2, the book value of equity excluding goodwill (BV_GWS) remains highly statistically significant after excluding goodwill despite goodwill being found to constitute a large part of net assets. Specifically, the model 2 coefficients are 0.454 for BV_GWS and 2.830 for EPS (both statistically significant at the $1 \%$ level). With reference to purchased goodwill, the estimated coefficient of GWS is positive (1.084) and highly statistically significant (at the $1 \%$ level). Hence, it can be inferred with sufficient certainty that the first hypothesis is confirmed and that the fair value measurement of goodwill under IFRS generally leads to relevant information.

[Insert Table 7 about here]

Regarding the second hypothesis, model 3 tests whether there is a systematic difference in goodwill's valuation effects between companies with relatively high and relatively low levels of compliance (LC). Here, the focal point of interest is the coefficient of the interaction variable GWS*DLC, where DLC equals one if LC is equal to or greater than the sample's median LC and zero otherwise. To calculate the LC, two approaches (unweighted and weighted) are employed to minimize the probability that the results are driven by the compliance measurement method. Thus, model 3 is estimated twice, and the final four columns of Table 7 provide the coefficients and respective standard errors of the estimations under both LC measurement approaches. The findings are similar under both approaches and confirm the second hypothesis. Specifically, under the unweighted (weighted) approach, the BV_GWS coefficient is 0.451 (0.477), and the EPS coefficient is 2.664 (2.550), with all coefficients being significant at the $1 \%$ level. Moreover, under both approaches, the GWS coefficient is found to be positive but not statistically significant, whereas the coefficient of the interaction variable GWS*DLC is positive and statistically significant at the 5\% level (1.075 and 1.133 under the unweighted and weighted approaches, respectively). These findings indicate that there is a systematic difference in goodwill's value relevance between companies with high and low levels of compliance with disclosure requirements. In particular, it can be inferred that goodwill has a strong effect on the equities' market valuation of companies with high compliance but no effect on that of companies with low compliance.

\subsection{Robustness test}

As discussed earlier, it is reasonable to assume that companies' level of compliance with IFRS disclosure requirements for goodwill may be driven by the magnitude of purchased goodwill accumulated on their balance sheets. In section 5.2, some evidence is provided that companies that differ in terms of level of compliance do not differ in terms of the magnitude of purchased goodwill accumulated on their balance sheets. In this section, further evidence concerning this issue is provided. Specifically, the three models are re-estimated utilizing a sub-sample in which companies below the $25^{\text {th }}$ percentile in terms of goodwill-to-total-assets ratio in the sample are excluded. Companies with a very small (relative to their size) amount of accumulated goodwill recognized on their balance sheets may decide not to provide detailed disclosures about goodwill because there is no additional value at risk in the case of goodwill impairment losses. In contrast, the remaining companies in the examined sub-sample carry a relatively large amount of goodwill ${ }^{8}$; consequently, it can be assumed that they share similar impairment risks.

[Insert Table 8 about here]

\footnotetext{
${ }^{8}$ The remaining companies in the sub-sample under examination have a goodwill-to-total-assets ratio of at least $1 \%$.
} 
The examined sub-sample consists of 56 observations. Out of the initial 81 companies, 20 belong to the bottom $25 \%$ and are eliminated. In addition, five more observations are excluded because they are identified by Cook's distance statistic as highly influential. Table 8 presents the results of the three models. The estimated coefficients of the sub-sample are statistically and economically similar to those of the initial multivariate analysis of the 76 companies (Table 7). Hence, it can be inferred with even greater certainty that purchased goodwill is value relevant only in companies that comply highly with IFRS disclosure requirements, regardless of the magnitude of goodwill.

\section{Discussion and conclusions}

The purpose of this study is to enrich the ongoing debate upon the accounting treatment of purchased goodwill under IFRS. It attempts to draw attention to the market valuation implications of goodwill under IFRS in a country outside the Anglo-Saxon accounting paradigm, where goodwill's value relevance has not been thoroughly examined. In countries that differ substantially from the institutional environment and accounting tradition of the so-called Anglo-Saxon countries, the extensive use of FVA may lead to measurement failures (intentional or unintentional on the part of the management), especially for accounting numbers that result from 'mark to model' estimates (Ball, 2006). This study provides empirical evidence that, despite its severe criticism, the use of 'mark to model' estimations results in relevant accounting numbers, even in an environment regarded as unfavorable for the implementation of IFRS in general and FVA in particular. Specifically, the findings reveal that purchased goodwill conveys relevant information for ASE participants. The goodwill coefficient is positive and statistically significant; thus, it can be inferred that goodwill "reflects information relevant to investors in valuing the firm and is measured reliably enough to be reflected in share prices" (Barth et al., 2001, p. 80).

A possible explanation for this result is given by Scott (2012). Over the last several years, the efficiency of capital markets and consequently investors' collective rationality have been questioned. To the extent that a capital market is not fully efficient, the application of FVA may enhance the decision usefulness of financial reporting because it may help investors assess more accurately future cash flows than historical cost financial statements do (Scott, 2012). On this basis, it could be speculated that because the efficiency of ASE is questionable (Dicle \& Levendis, 2011), the high value relevance of goodwill could be attributed to the extent of ASE efficiency. This is an open empirical question for future research.

Although purchased goodwill is found to be value relevant, a potential negative consequence of its accounting treatment under IFRS is the accumulation of large amounts of goodwill on companies' balance sheets, especially in times of rising prices and stable markets. This accumulated goodwill may represent a substantial risk in 'bad times' if companies have to write it off and recognize impairment losses. Nevertheless, the findings of this study show that accumulated goodwill has a positive impact on a company's market valuation only if the company exhibits a high level of compliance with mandatory disclosure requirements for goodwill. Thus, a high level of compliance is an important factor that enables investors to interpret the effects of accounting numbers on the future performance of the company (Kang \& Pang, 2005). In contrast, if a company exhibits a low level of compliance, goodwill is not found to be value relevant, which indicates that investors do not expect (and hence do not discount) any future economic benefit from goodwill; in other words, they 'write off' goodwill before companies do. These results are indicative of the importance of IFRS mandatory disclosures, especially for accounting items that are heavily influenced by FVA. Although prior studies conclude that the value relevance of net assets at an aggregated level (that is, the book value of equity) does not differ between companies with high and low levels of compliance with IFRS disclosure requirements (Paananen, 2008; Tsalavoutas \& Dionysiou, 2013), this study shows that for specific assets that are heavily influenced by FVA (such as purchased goodwill), their value relevance might differ by the level of compliance with disclosure requirements. 
In summary, the purpose of this study is to provide evidence that FVA generates relevant accounting numbers but only under specific conditions. At an aggregated level, the purchased goodwill of companies listed in the ASE is value relevant. Hence, it can be inferred that FVA produces relevant accounting information even in environments that are unfavorable for the application of IFRS. Nevertheless, a highly transparent annual report seems to be a crucial prerequisite of the relevance of the accounting numbers, at least in the case of mandatory disclosures for purchased goodwill, as companies that fail to comply with the disclosure requirements of IFRS suffer non-relevance of their accounting numbers.

\section{Acknowledgments}

We would like to thank an anonymous reviewer and Glen Lehman (the editor) for valuable suggestions and comments. Earlier versions of this study have been benefited from participants' comments at the 14th Annual Conference of the Financial Accounting and Reporting Special Interest Unit of the British Accounting Association in Bristol, UK; at the 2010 Nordic Accounting Conference in Copenhagen, Denmark and at a research seminar at the Åbo Akademi University, Finland, invited by Professor Lars Hassel.

\section{References}

[44] D. Aboody, B. Lev, The value relevance of intangibles: The case of software capitalization, Journal of Accounting Research, 36, (1998) 161-191.

[60] A.S. Ahmed, R.M. Morton, T.F. Schaefer Accounting conservatism and the valuation of accounting numbers: Evidence on the Feltham-Ohlson (1996) model, Journal of Accounting, Auditing \& Finance, 153 (2000) 271-292.

[3] R. Ball, International financial reporting standards: Pros and cons for investors, Accounting and Business Research, 361 (2006) 5-27.

[20] A.A. Ballas, Accounting in Greece, European Accounting Review, 31 (1994) 107-121.

[10] A.A. Ballas, D. Hevas, D. Neal, The state of accounting and the state of the state, Journal of Management and Governance, 23 (1998) 267-285.

[33] A.A. Ballas, D. Skoutela, C. Tzovas, The relevance of IFRS to an emerging market: evidence from Greece, Managerial Finance, 3611 (2010) 931-948.

[39] A.A. Ballas, C. Tzovas, An empirical investigation of Greek firms' compliance to IFRS disclosure requirements, International Journal of Managerial and Financial Accounting, 21 , (2010) 40-62.

[19] K. Bae, H. Tan, M. Welker, International GAAP differences: The impact on foreign analysts, The Accounting Review, 833 (2008) 593-628.

[49] E. M. Barth, H. W. Beaver, R. W. Landsman, The relevance of the value relevance literature for financial accounting standard setting: another view, Journal of Accounting and Economics, 31 1-3 (2001) 77-104.

[46] E. M. Barth, G. Clinch, Scale effects in capital markets-based accounting research, Journal of Business Finance and Accounting, 36 3-4 (2009) 253-288.

[9] L.A. Beisland, Equity valuation in practice: The influence of net financial expenses, Accounting Forum (2013), http://dx.doi.org/10.1016/j.accfor.2013.04.008 
[27] M. Bugeja, N. Gallery, Is older goodwill value relevant?, Accounting and Finance, 464 (2006) 519-535.

[30] K. Chalmers, G. Clinch, M. J. Godfrey, Adoption of International Financial Reporting Standards: Impact on the value relevance of intangible assets, Australian Accounting Review, 183 (2008) 237-247.

[24] K. W. Chauvin, M. Hirschey, Goodwill, profitability and the market value of the firm, Journal of Accounting and Public Policy, 132 (1994) 159-180.

[61] D.W. Collins, E.L. Maydew, I.S. Weiss, Changes in the value relevance of earnings and book values over the past forty years, Journal of Accounting and Economics, 241 (1997) 39-67.

[36] Committee of European Securities Regulators, Activity report on IFRS enforcement 2009, [online] Available from http://www.esma.europa.eu/system/files/10_917.pdf (accessed 28 February 2011)

[56] T. E. Cooke, Voluntary corporate disclosure by Swedish companies, Journal of International Financial Management and Accounting, 12 (1989) 171-195.

[1] J. Cooper, Debating accounting principles and policies: the case of goodwill, 1880-1921, Accounting, Business and Financial History, 1723 (2007) 241-264.

[28] N. F. Dahmash, B. R. Durand, J. Watson, The value relevance and reliability of reported goodwill and identifiable intangible assets, The British Accounting Review s 412 (2009) 120-137.

[50] Deloitte Touche Tohmatsu, International Financial Reporting Standards-Presentation and disclosure checklist, [online] Available from: http://www.iasplus.com/ fs/2008checklist.pdf (accessed 30 June 2009)

[65] M. F. Dicle, J. Levendis, Greek market efficiency and its international integration, Journal of International Financial Markets, Institutions \& Money, 21, 2 (2011) 229-246.

[18] Y. Ding, O. K. Hope, T. Jeanjean, H. Stolowy, Differences between domestic accounting standards and IAS: Measurement, determinants and implication, Journal of Accounting and Public Policy, 261 (2007) 1-38.

[22] C. Eckstein, The measurement and recognition of intangible assets: then and now, Accounting Forum, 282 (2004) 139-158.

[23] N. El-Tawy, T. Tollington, Some thoughts on the recognition of assets, notably in respect of intangible assets, Accounting Forum, 371 (2013) 67-80.

[53] Ernst \& Young, International GAAP disclosure checklist, [online] available from: http://www.ey.com/Publication/vwLUAssets/IFRS_GAAP_Disclosure_checklist_2008/\$FI LE/IFRS_Disclosure_Checklist_2008.pdf (accessed 30 August 2009)

[38] S. Fekete, D. Matis, J. Lukács, Factors influencing the extent of corporate compliance with IFRS - The case of Hungarian listed companies, Social Science Research Network working paper, (2008)

[5] A. Franklin, E. Carletti, Mark-to-market accounting and liquidity pricing. Journal of Accounting and Economics, 45 2-3 (2008) 358-378.

[37] Financial Reporting Council, Review of goodwill impairment disclosures, [online] Available from: http://www.frc.org.uk/images/uploaded/documents/Review of goodwill impairment disclosures 280ct 2008 291.pdf (Accessed 30 August 2008)

[52] M. Glaum, L. D. Street, Compliance with the disclosure requirements of Germany's New Market: IAS versus US GAAP, Journal of International Financial Management and Accounting, 141 (2003) 64-100. 
[63] D. Gujarati, Basic econometrics, third ed., McGraw-Hill, New York, 1995

[62] C. Haslam, T. Andersson, N. Tsitsianis, Y.P. Yin, Business Models Redefined; Strategies for a Financialized World, Routledge, New York, 2013

[35] O. A. G. Hassan, P. Romilly, G. Giorgioni, The extent of financial disclosure and its determinants in an emerging capital market: The case of Egypt, International Journal of Accounting, Auditing and Performance Evaluation, 31 (2006) 41-67.

[47] C. Hayn, The information content of losses, Journal of Accounting and Economics, 202 (1995) 125-153.

[41] M. P. Healy, G. K. Palepu, Information asymmetry, corporate disclosure and the capital markets: A review of the empirical disclosure literature, Journal of Accounting and Economics, 31 13 (2001) 405-440.

[34] G. Iatridis, S. Rouvolis, The post-adoption effects of the implementation of International Financial Reporting Standards in Greece, Journal of International Accounting, Auditing and Taxation, 191 (2010) 55-65.

[57] A. Jahangir, A. Kamran, H. Darren, Disclosure compliance with national accounting standards by listed companies in South Asia, Accounting and Business Research, 343 (2004) 183-199.

[25] R. Jennings, J. Robinson, B. R. Thompson, L. Duvall, The relation between accounting goodwill numbers and equity values, Journal of Business Finance and Accounting, 234 (1996) 513533.

[43] K. E. Jermakowicz, S. Gornik-Tomaszewski, Implementing IFRS from the perspective of EU publicly traded companies, Journal of International Accounting, Auditing and Taxation, 152 (2006) 170-196.

[32] A. K. Jifri, D. Citron, The value relevance of financial statement recognition versus note disclosure: Evidence from goodwill accounting, European Accounting Review, 181 (2009) 123-140.

[48] P. Joos, A. G. Plesko, Valuing Loss Firms, The Accounting Review, 803 (2005) 847-870.

[42] T. Kang, H. Y. Pang, Economic development and the value relevance of accounting information - A disclosure transparency perspective, Review of Accounting and Finance, 41 (2005) 531.

[21] I. N. Karampinis, L. D. Hevas, Mandating IFRS in an unfavorable environment: the Greek experience, The International Journal of Accounting, 463 (2011) 304-332.

[54] KPMG, Disclosure checklist International Financial Reporting Standards, [online] available from:

https://www.in.kpmg.com/securedata/ifrs_Institute/Files/ifrs_disclosurechecklist2008.pdf (accessed 30 August 2009)

[12] C. Leuz, P. Wysocki, Economic consequences of financial reporting and disclosure regulation: A review and suggestions for future research, Social Science Research Network working paper, (2008).

[26] G. M. McCarthy, K. D. Schneider, Market perception of goodwill: Some empirical evidence, Accounting and Business Research, 261 (1995) 69-81.

[2] M.C. Miller, Goodwill-an aggregation issue, The Accounting Review, 48 2, (1973) 280-291.

[11] C. Nobes, Accounting classification in the IFRS era, Australian Accounting Review, 183 (2008) 191-198. 
[17] C. Nobes, IFRS Practices and the Persistence of Accounting System Classification, Abacus. 47 3, (2011) 267-283.

[45] A. J. Ohlson, Earnings, book values and dividends in equity valuation, Contemporary Accounting Research, 112 (1995) 661-687.

[31] H. Ojala, The value relevance of accounting goodwill - Does the abandonment of systematic amortization make sense to investors?, The Finnish Journal of Business Economics, 1 (2007) 9-34.

[51] B. H. Othman, D. Zeghal, Investigating transparency and disclosure Determinants at firm-level in MENA emerging markets, International Journal of Accounting, Auditing and Performance Evaluation, 64 (2010) 368-396.

[15] M. Paananen, Fair value accounting for goodwill under IFRS: An exploratory study of the comparability in France, Germany and the United Kingdom, Social Science Research Network working paper (2008)

[4] H. S. Penman, Financial reporting quality: Is fair value a plus or a minus?, Accounting and Business Research, 371 (2007) 33-44.

[55] Pricewaterhouse Coopers, IFRS Disclosure Checklist 2008, available at:https://pwcinform.pwc.com/inform2/show?action=informContent\&id=085807261114799 9\# (Accessed 30 August 2009)

[6] K. Ramanna, The implications of unverifiable fair value accounting: Evidence from the political economy of goodwill accounting, Journal of Accounting and Economics, 45 2-3 (2008) 253281.

[29] A. Ritter, P. Wells, Identifiable intangible asset disclosure, stock prices and future earnings, Accounting and Finance, 465 (2006) 843-863.

[13] K. Schipper, Required disclosures in financial reporting, The Accounting Review, 822 (2007) 301-326.

[64] W. R. Scott, Financial Accounting Theory, sixth ed., Pearson, Toronto, 2012

[40] P. Sengupta, Corporate disclosure quality and the cost of debt, The Accounting Review, 734 (1998) 459-474.

[7] S. Sevin, R. Schroeder, Earnings management: Evidence from SFAS No. 142 reporting, Managerial Auditing Journal, 201 (2005) 47-54.

[59] L. D. Street, J. S. Gray, Factors influencing the extent of corporate compliance with International Accounting Standards: Summary of a research monograph, Journal of International Accounting Auditing and Taxation, 111 (2002) 51-76.

[16] I. Tsalavoutas, D. Dionysiou, Value relevance of IFRS mandatory disclosure requirements, Journal of Applied Accounting Research, 141 (2013)

[58] I. Tsalavoutas, L. Evans, M. Smith, Comparison of two methods for measuring compliance with IFRS mandatory disclosure requirements, Journal of Applied Accounting Research, 113 (2010) 213-228.

[8] G. Wines, R. Dagwell, C. Windsor, Implications of the IFRS goodwill accounting treatment, Managerial Auditing Journal, 229 (2007) 862-880.

[14] D. Zéghal, A. Maaloul, The accounting treatment of intangible - A critical review of the literature, Accounting Forum, 354 (2011) 262-274. 


\section{Tables}

Table 1: Valuation methods employed in business combination accounted by the acquisition method under IFRS and Greek accounting regulation

IFRS

\begin{tabular}{l}
\hline Tangible Assets \\
Intangible Assets \\
Financial Instruments \\
traded in an active market \\
Financial Instruments \\
not traded in an active market
\end{tabular}

Inventories

Liabilities (except taxes and employee benefits)

\section{Greek Accounting Regulation}

Fair Values

Current Values

Historical Cost / Fair Values

Fair Values

Valuation based on similar instruments that can be measured reliable

Selling price

(-) disposal cost (-) profit margin

Present values discounted by the appropriate rate

\section{Historical Cost}

Lower value between acquisition cost and average market value of the last month

Lower value between acquisition cost and carrying value

Lower value between acquisition cost and current value

Table 2. Companies selection process

Companies with purchased goodwill

less companies belonging to the banking and financial services sectors

less companies with fiscal year-end on June $30^{\text {th }}$

less companies with negative book value of equity

less highly influential observations identified by Cook's distance statistic 
Table 3. Summary statistics of companies' level of compliance per standard and measurement approach

\begin{tabular}{lcccccc}
\hline & Mean & Median & Std. Dev. & Min & Max & N \\
\hline IFRS 3 & 0.82 & 1.00 & 0.23 & 0.17 & 1.00 & 76 \\
IAS 36 & 0.29 & 0.14 & 0.35 & 0.00 & 1.00 & 75 \\
LC_u & 0.49 & $0.44^{\mathbf{b}}$ & 0.25 & 0.12 & 1.00 & 76 \\
LC_w & 0.56 & $0.51^{\mathbf{b}}$ & 0.23 & 0.09 & 1.00 & 76 \\
\hline
\end{tabular}

LC_u is the level of compliance measured by the unweighted approach and $\mathrm{LC}_{-} \mathrm{w}$ is the level of compliance measured by the weighted approach.

${ }^{a}$ In one case IAS 36 found to be not applicable

b A non-parametric Wilcoxon Signed Rank test revealed a statistically significant difference between LC_u and LC_w $(\mathrm{z}=-3.508, \mathrm{p}=0.001)$

Table 4. Companies' distribution per compliance group and industry

\begin{tabular}{|c|c|c|c|c|c|c|}
\hline \multirow{2}{*}{ Industry } & \multicolumn{2}{|c|}{ Unweighted Approach } & \multicolumn{2}{|c|}{ Weighted Approach } & \multirow{2}{*}{ Total } & \multirow{2}{*}{$\mathbf{f}(\%)$} \\
\hline & Low LC & High LC & Low LC & High LC & & \\
\hline Basic Resources & 1 & 2 & 2 & 1 & 3 & $4 \%$ \\
\hline Chemicals & 3 & 1 & 3 & 1 & 4 & $5 \%$ \\
\hline Construction and Materials & 6 & 4 & 6 & 4 & 10 & $13 \%$ \\
\hline Food \& Beverage & 9 & 3 & 8 & 4 & 12 & $16 \%$ \\
\hline Health Care & 3 & 4 & 2 & 5 & 7 & $9 \%$ \\
\hline Industrial Goods \& Services & 4 & 7 & 3 & 8 & 11 & $14 \%$ \\
\hline Media & 3 & 2 & 2 & 3 & 5 & $7 \%$ \\
\hline Oil \& Gas & 1 & 1 & 1 & 1 & 2 & $3 \%$ \\
\hline Personal \& Household Goods & 4 & 3 & 4 & 3 & 7 & $9 \%$ \\
\hline Real Estate & 0 & 1 & 0 & 1 & 1 & $1 \%$ \\
\hline Retail & 0 & 2 & 1 & 1 & 2 & $3 \%$ \\
\hline Technology & 3 & 7 & 5 & 5 & 10 & $13 \%$ \\
\hline Travel and Leisure & 1 & 0 & 1 & 0 & 1 & $1 \%$ \\
\hline Utilities & 0 & 1 & 0 & 1 & 1 & $1 \%$ \\
\hline Total & 38 & 38 & 38 & 38 & 76 & $100 \%$ \\
\hline
\end{tabular}

Under the 'Low LC' ('High LC') headings, companies with level of compliance (LC) lower (equal to or higher) than the median of sample's LC are summarized 
Table 5. Descriptive statistics

\begin{tabular}{|c|c|c|c|c|c|c|c|c|c|c|c|c|c|c|c|}
\hline & \multirow{2}{*}{\multicolumn{3}{|c|}{ Full Sample (N=76) }} & \multicolumn{6}{|c|}{ Unweighted Approach } & \multicolumn{6}{|c|}{ Weighted Approach } \\
\hline & & & & \multicolumn{3}{|c|}{ Low $(\mathbf{N}=38)$} & \multicolumn{3}{|c|}{ High $(\mathrm{N}=38)$} & \multicolumn{3}{|c|}{ Low $(N=38)$} & \multicolumn{3}{|c|}{ High $(\mathrm{N}=38)$} \\
\hline & Mean & $\begin{array}{c}\text { Media } \\
\text { n }\end{array}$ & S.D. & Mean & Median & S.D. & Mean & Median & S.D. & Mean & Median & S.D. & Mean & Median & S.D. \\
\hline \multicolumn{16}{|c|}{ Panel A Basic descriptives of the regressions variables } \\
\hline PR & 2,79 & 1,39 & 3,34 & 1,78 & 0,96 & 2,04 & 3,80 & 1,99 & 4,05 & 2,19 & 1,36 & 2,18 & 3,38 & 1,43 & 4,14 \\
\hline BVS & 2,69 & 2,12 & 2,76 & 1,83 & 1,50 & 1,38 & 3,55 & 2,68 & 3,47 & 2,38 & 2,22 & 2,01 & 2,99 & 1,87 & 3,35 \\
\hline BV_GWS & 2,10 & 1,42 & 2,29 & 1,56 & 1,28 & 1,32 & 2,64 & 1,66 & 2,87 & 2,04 & 1,53 & 1,90 & 2,17 & 1,25 & 2,64 \\
\hline GWS & 0,58 & 0,21 & 0,99 & 0,26 & 0,12 & 0,40 & 0,90 & $\mathbf{0 , 4 2}$ & 1,27 & 0,34 & 0,19 & 0,45 & 0,83 & 0,26 & 1,29 \\
\hline EPS & 0,26 & 0,12 & 0,58 & 0,15 & 0,10 & 0,42 & 0,37 & 0,23 & 0,70 & 0,24 & 0,12 & 0,43 & 0,28 & 0,11 & 0,71 \\
\hline \multicolumn{16}{|c|}{ Binary variables } \\
\hline IND & 0,39 & 0,00 & 0,49 & 0,39 & 0,00 & 0,50 & 0,39 & 0,00 & 0,50 & 0,39 & 0,00 & 0,50 & 0,39 & 0,00 & 0,50 \\
\hline LOSS & 0,25 & 0,00 & 0,44 & 0,29 & 0,00 & 0,46 & 0,21 & 0,00 & 0,41 & 0,18 & 0,00 & 0,39 & 0,32 & 0,00 & 0,47 \\
\hline DLC_u & 0,50 & 0,50 & 0,50 & & & & & & & & & & & & \\
\hline DLC_w & 0,50 & 0,50 & 0,50 & & & & & & & & & & & & \\
\hline \multicolumn{16}{|c|}{ Panel B Supplementary descriptives of the sample } \\
\hline GW/TA & 0,06 & 0,03 & 0,07 & 0,05 & $\mathbf{0 , 0 3}$ & 0,06 & 0,08 & 0,05 & 0,08 & 0,05 & 0,03 & 0,06 & 0,08 & 0,04 & 0,08 \\
\hline GW/BV & 0,23 & 0,13 & 0,28 & 0,18 & 0,11 & 0,23 & 0,29 & 0,17 & 0,31 & 0,17 & 0,12 & 0,19 & 0,29 & 0,15 & 0,33 \\
\hline
\end{tabular}

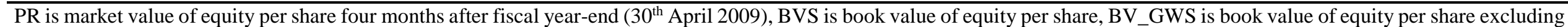

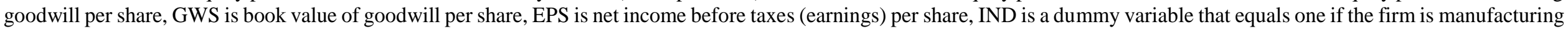

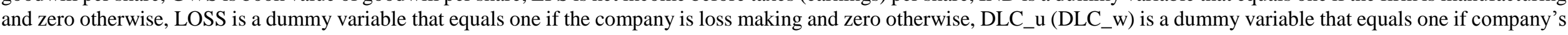
LC_u (LC_w) is higher or equal than sample's median LC_u (LC_w) and zero otherwise.

GW/TA is the ratio of purchased goodwill to total assets and GW/BV is the ratio of purchased goodwill to book value of equity

A non-parametric Mann-Whitney test is performed for comparing the descriptives between low and high compliant companies under both compliance measurement approach.

Figures in bold indicate statistical significance at least at $5 \%$ level 
Table 6 Correlation matrix of variables

\begin{tabular}{lccccccccc}
\hline & PR & BVS & BV_GWS & GWS & EPS & IND & LOSS & D1 & D2 \\
\hline PR & & $\mathbf{0 , 8 0}$ & $\mathbf{0 , 7 0}$ & $\mathbf{0 , 6 1}$ & $\mathbf{0 , 7 7}$ & 0,19 & $-0,30$ & 0,30 & 0,18 \\
BVS & $\mathbf{0 , 7 5}$ & & $\mathbf{0 , 9 4}$ & $\mathbf{0 , 6 2}$ & $\mathbf{0 , 6 5}$ & $\mathbf{0 , 2 6}$ & $-0,23$ & $\mathbf{0 , 3 1}$ & 0,11 \\
BV_GWS & $\mathbf{0 , 6 8}$ & $\mathbf{0 , 8 9}$ & & $\mathbf{0 , 3 1}$ & $\mathbf{0 , 6 1}$ & $\mathbf{0 , 3 2}$ & $\mathbf{- 0 , 2 7}$ & $\mathbf{0 , 2 4}$ & 0,03 \\
GWS & $\mathbf{0 , 2 9}$ & $\mathbf{0 , 4 9}$ & 0,17 & & $\mathbf{0 , 3 9}$ & $-0,03$ & $-0,02$ & $\mathbf{0 , 3 3}$ & $\mathbf{0 , 2 5}$ \\
EPS & $\mathbf{0 , 7 0}$ & $\mathbf{0 , 5 3}$ & $\mathbf{0 , 5 7}$ & $\mathbf{0 , 2 5}$ & & 0,19 & $\mathbf{- 0 , 5 6}$ & 0,20 & 0,03 \\
IND & 0,10 & 0,21 & $\mathbf{0 , 3 1}$ & $-0,07$ & 0,18 & & $-0,09$ & 0,00 & 0,00 \\
LOSS & $\mathbf{- 0 , 4 3}$ & $\mathbf{- 0 , 2 9}$ & $\mathbf{- 0 , 3 9}$ & $-0,09$ & $\mathbf{- 0 , 7 5}$ & $-0,09$ & & $-0,09$ & 0,15 \\
D1 & $\mathbf{0 , 3 2}$ & $\mathbf{0 , 3 0}$ & 0,17 & $\mathbf{0 , 3 2}$ & 0,18 & 0,00 & $-0,09$ & & $\mathbf{0 , 5 3}$ \\
D2 & 0,07 & 0,04 & $-0,05$ & 0,13 & $-0,02$ & 0,00 & 0,15 & $\mathbf{0 , 5 3}$ & \\
\hline Spean
\end{tabular}

Spearman's rank correlation coefficients and Pearson's correlation coefficients are provided above and below the diagonal respectively

Figures in bold indicate statistical significance at least at $5 \%$ level

Variables definitions are provided on Table 5

Table 7. Regressions results

\begin{tabular}{|c|c|c|c|c|c|c|c|c|}
\hline \multirow{4}{*}{\begin{tabular}{|l} 
Model 1: $P R_{i}=$ \\
Model 2: $P R_{i}=$ \\
Model 3: $P R_{i}=$ \\
\\
Variables \\
\end{tabular}} & \multirow{3}{*}{\multicolumn{2}{|c|}{ Model 1}} & \multirow{3}{*}{\multicolumn{2}{|c|}{ Model 2}} & \multirow{2}{*}{\multicolumn{4}{|c|}{ Model 3}} \\
\hline & & & & & & & & \\
\hline & & & & & \multicolumn{2}{|c|}{ Unweighted Approach } & \multicolumn{2}{|c|}{ Weighted Approach } \\
\hline & Coef & $S E$ & Coef & $S E$ & Coef. & $S E$ & Coef. & $S E$ \\
\hline Constant & 0.313 & 0.23 & 0.323 & 0.22 & 0.595 & 0.39 & 0.574 & 0.37 \\
\hline BVS & 0.596 & $0.10 * * *$ & & & & & & \\
\hline EPS & 2.957 & $0.70 * * *$ & & & & & & \\
\hline BV_GWS & & & 0.454 & $0.12 * * *$ & 0.451 & $0.12 * * *$ & 0.477 & $0.11 * * *$ \\
\hline GWS & & & 1.084 & $0.30 * * *$ & 0.103 & 0.33 & 0.056 & 0.31 \\
\hline EPS & & & 2.830 & $0.73 * * *$ & 2.664 & $0.78 * * *$ & 2.550 & $0.79 * * *$ \\
\hline DLC & & & & & -0.090 & 0.48 & 0.053 & 0.89 \\
\hline GWS×DLC & & & & & 1.075 & $0.51 * *$ & 1.133 & $0.47 * *$ \\
\hline \multicolumn{9}{|l|}{ Controls } \\
\hline IND & -0.198 & 0.45 & 0.053 & 0.45 & -0.033 & 0.46 & -0.022 & 0.45 \\
\hline LOSS & 0.735 & 0.46 & 0.485 & 0.49 & 0.259 & 0.54 & -0.111 & 0.53 \\
\hline $\mathbf{N}$ & \multicolumn{2}{|c|}{76} & \multicolumn{2}{|c|}{76} & \multicolumn{2}{|c|}{76} & \multicolumn{2}{|c|}{76} \\
\hline F-stat & \multicolumn{2}{|c|}{$37.48 * * *$} & \multicolumn{2}{|c|}{$57.97 * * *$} & \multicolumn{2}{|c|}{$50.16^{* * *}$} & \multicolumn{2}{|c|}{$50.88 * * *$} \\
\hline Adj. $R^{2}$ & \multicolumn{2}{|c|}{0.757} & \multicolumn{2}{|c|}{0.777} & \multicolumn{2}{|c|}{0.785} & \multicolumn{2}{|c|}{0.790} \\
\hline
\end{tabular}

Under the unweighted approach the level of compliance LC_u and under the weighted approach the LC_w are used respectively for dividing the companies into "high complied" and "low complied" groups.

$* * *, * *$ and $*$ denote statistical significance at $1 \%, 5 \%$ and $10 \%$ level respectively

Standard errors are based on White's adjustments

Variables definitions are provided on Table 5 
Table 8. Regressions results - robustness test

\begin{tabular}{|c|c|c|c|c|c|c|c|c|}
\hline \multirow{3}{*}{\multicolumn{3}{|c|}{$\begin{array}{l}\text { Model 1: } P R_{i}=\alpha_{0}+a_{l} B V S_{i}+a_{2} E P S_{i} \\
\text { Model 2: } P R_{i}=\alpha_{0}+a_{1} B V_{-} G W S_{i}+a_{2} C \\
\text { Model 3: } P R_{i}=\alpha_{0}+a_{1} B V_{-} G W S_{i}+a_{2} C \\
\end{array}$}} & \multirow{3}{*}{\multicolumn{2}{|c|}{ Model 2}} & \multirow{2}{*}{\multicolumn{4}{|c|}{ Model 3}} \\
\hline & & & & & & & & \\
\hline & & & & & \multicolumn{2}{|c|}{ Unweighted Approach } & \multicolumn{2}{|c|}{ Weighted Approach } \\
\hline Variables & Coef & $S E$ & Coef & $S E$ & Coef. & $S E$ & Coef. & $S E$ \\
\hline Constant & 0.089 & 0.27 & 0.042 & 0.28 & 0.761 & 0.58 & 0.799 & 0.67 \\
\hline BVS & 0.643 & $0.13^{* * *}$ & & & & & & \\
\hline EPS & 2.816 & $0.84 * * *$ & & & & & & \\
\hline BV_GWS & & & 0.399 & $0.17 * *$ & 0.415 & $0.16^{* *}$ & 0.380 & $0.18 * *$ \\
\hline GWS & & & 1.408 & $0.35 * * *$ & 0.097 & 0.48 & 0.023 & 0.60 \\
\hline EPS & & & 2.591 & $0.83 * * *$ & 2.289 & $0.88^{* *}$ & 2.430 & $0.87 * * *$ \\
\hline DLC & & & & & -0.672 & 0.58 & -0.822 & 0.79 \\
\hline GWS×DLC & & & & & 1.510 & $0.61 * *$ & 1.548 & $0.76^{* *}$ \\
\hline Controls & & & & & & & & \\
\hline IND & -0.192 & 0.57 & 0.267 & 0.56 & 0.027 & 0.55 & 0.281 & 0.61 \\
\hline LOSS & 0.891 & 0.53 & 0.539 & 0.55 & 0.151 & 0.61 & 0.418 & 0.55 \\
\hline $\mathbf{N}$ & \multicolumn{2}{|c|}{56} & \multicolumn{2}{|c|}{56} & \multicolumn{2}{|c|}{56} & \multicolumn{2}{|c|}{56} \\
\hline F-stat & \multicolumn{2}{|c|}{$35.00 * * *$} & \multicolumn{2}{|c|}{$76.69 * * *$} & \multicolumn{2}{|c|}{$74.67 * * *$} & \multicolumn{2}{|c|}{$69.98 * * *$} \\
\hline $\operatorname{Adj} . \mathbf{R}^{2}$ & \multicolumn{2}{|c|}{0.771} & \multicolumn{2}{|c|}{0.811} & \multicolumn{2}{|c|}{0.822} & \multicolumn{2}{|c|}{0.821} \\
\hline
\end{tabular}

Under the unweighted approach the level of compliance LC_1 and under the weighted approach the LC_2 are used respectively for dividing the companies into "high complied" and "low complied" groups.

$* * *, * *$ and $*$ denote statistical significance at $1 \%, 5 \%$ and $10 \%$ level respectively

Standard errors are based on White's adjustments

Variables definitions are provided on Table 5 


\title{
APPENDIX A: Disclosures Checklist (the items under examination are shaded)
}

\author{
IFRS 3, version including amendments issued up to 17 January 2008
}

IFRS 3 Par. 62 Where the acquirer has made adjustments to provisional values determined at the time of the initial accounting for a business combination, in accordance with the requirements of paragraph 62 of IFRS 3 , comparative information presented for the periods before the initial accounting for the combination is complete (i.e. for periods before the adjustments are made) shall be presented as if the initial accounting had been completed from the acquisition date.

IFRS 3 Par. 67 For each material business combination that was effected during the period, the acquirer shall disclose:

IFRS 3.67(a) a) the names and descriptions of the combining entities or businesses;

IFRS 3.67(b) b) the acquisition date;

IFRS $3.67(\mathrm{c}) \quad$ c) the percentage of voting equity instruments acquired;

IFRS 3.67(d) d) the cost of the combination, and a description of the components of that cost, including any costs directly attributable to the combination;

IFRS 3.67(d) e) where equity instruments are issued or issuable as part of the cost of the combination, the following information:

i) the number of equity instruments issued or issuable;

ii) the fair value of the equity instruments issued or issuable; and

iii) the basis for determining that fair value;

IFRS 3.67(d) f) in disclosing the basis for determining the fair value of equity instruments issued or issuable as part of the cost of the combination, if a published price for the instruments did not exist at the date of exchange, the significant assumptions used to determine fair value;

IFRS 3.67(d) g) in disclosing the basis for determining the fair value of equity instruments issued or issuable as part of the cost of the combination, if a published price for the instruments existed at the date of exchange, but was not used as the basis for determining the cost of the combination:

\begin{tabular}{|c|c|}
\hline & that fact; \\
\hline & the reasons the published price was not used; \\
\hline & $\begin{array}{l}\text { iii) the method and significant assumptions used to attribute a value to the equity instruments; and } \\
\text { iv) the aggregate amount of the difference between the value attributed to, and the published price }\end{array}$ \\
\hline IFRS 3.67(e) & $\begin{array}{l}\text { of, the equity instruments; } \\
\text { h) details of any operations the entity has decided to dispose of as a result of the business combination; }\end{array}$ \\
\hline IFRS 3.67(f) & $\begin{array}{l}\text { i) the amounts recognized at the acquisition date for each class of the acquiree's assets, liabilities and } \\
\text { contingent liabilities; }\end{array}$ \\
\hline IFRS 3.67(f) & $\begin{array}{l}\text { j) unless disclosure would be impracticable, the carrying amounts of each class of the acquiree's } \\
\text { assets, liabilities and contingent liabilities, determined in accordance with IFRSs, immediately before } \\
\text { the combination; }\end{array}$ \\
\hline IFRS 3.67(f) & $\begin{array}{l}\text { k) if disclosure of such IFRS carrying amounts immediately before combination is impracticable, that } \\
\text { fact, together with an explanation of why this is the case; }\end{array}$ \\
\hline IFRS 3.67(h) & 1) a description of the factors that contributed to a cost that results in the recognition of goodwill \\
\hline & a description of each intangible asset that was not recognized separately from goodwill; and \\
\hline & ii) an explanation of why the intangible asset's fair value could not be measured reliably; \\
\hline IFRS $3.67(\mathrm{~g})$ & $\begin{array}{l}\text { m) in respect of any excess of the acquirer's interest in the net fair value of the acquiree's } \\
\text { identifiable assets, liabilities and contingent liabilities over cost: }\end{array}$ \\
\hline & $\begin{array}{l}\text { i) the amount of any such excess recognized in profit or loss in accordance with paragraph } 56 \\
\text { of IFRS 3; and }\end{array}$ \\
\hline & the line item in the statement of comprehensive income in which the excess is recognized; \\
\hline IFRS $3.67(\mathrm{~h})$ & $\begin{array}{l}\text { n) a description of the nature of any excess of the acquirer's interest in the net fair value of the } \\
\text { acquiree's identifiable assets, liabilities and contingent liabilities over cost, recognized in profit or } \\
\text { loss in accordance with paragraph } 56 \text { of IFRS 3; }\end{array}$ \\
\hline IFRS 3.67(i) & $\begin{array}{l}\text { o) unless impracticable, the amount of the acquiree's profit or loss since the acquisition date } \\
\text { included in the acquirer's profit or loss for the period; and }\end{array}$ \\
\hline
\end{tabular}


p) if it is impracticable to disclose the amount of the acquiree's profit or loss since the acquisition date included in the acquirer's profit or loss for the period that fact; and an explanation of why this is the case.

IFRS 3 Par. 69 If the initial accounting for a business combination that was effected during the period has been determined only provisionally as described in paragraph 62 of IFRS 3, the entity shall disclose that fact and an explanation of why this is the case

IFRS 3 Par. 70 Unless impracticable, the following information shall be disclosed:

IFRS 3.70(a) a) the revenue of the combined entity for the period as though the acquisition date for all business combinations effected during the period had been the beginning of the period; and

IFRS 3.70(b) b) the profit or loss of the combined entity for the period as though the acquisition date for all business combinations effected during the period had been the beginning of the period.

IFRS 3.70 If disclosure of the information required by paragraphs 70(a) and 70(b) of IFRS 3 (see above) would be impracticable, the entity shall disclose that fact and an explanation of why this is the case

IFRS 3 Par. 72 The acquirer shall disclose information that enables users of its financial statements to evaluate the financial effects of gains, losses, error corrections and other adjustments recognized in the current period that relate to business combinations that were effected in the current or in previous periods.

IFRS 3 Par. 73 The entity shall disclose:

IFRS 3.73(a) a) the amount, and an explanation, of any gain or loss recognized in the current reporting period that relates to the identifiable assets acquired or liabilities or contingent liabilities assumed in a business combination that was effected in either the current or a previous period and is of such a size, nature or incidence that disclosure is relevant to an understanding of the combined entity's financial performance;

IFRS 3.73(b) b) if the initial accounting for a business combination that was effected in the immediately preceding period was determined only provisionally at the end of that period, the amounts, and explanations, of adjustments to the provisional values recognized during the current period; and

IFRS 3 Par. 75 The entity shall disclose a reconciliation of the carrying amount of goodwill at the beginning and end of the period, showing separately:

IFRS 3.75(a) a) the gross amount and accumulated impairment losses at the beginning of the period;

IFRS 3.75(b) b) additional goodwill recognized during the period, except where that goodwill is included in a disposal group that, on acquisition, meets the criteria to be classified as held for sale in accordance with IFRS 5 Non-current Assets Held for Sale and Discontinued Operations;

IFRS 3.75(c) c) adjustments resulting from the subsequent recognition of deferred tax assets during the period in accordance with paragraph 65 of IFRS 3;

IFRS 3.75(d) d) goodwill included in a disposal group classified as held for sale in accordance with IFRS 5 and goodwill derecognized during the period without having previously been included in a disposal group classified as held for sale;

IFRS 3.75(e) e) impairment losses recognized during the period in accordance with IAS 36 Impairment of Assets;

IFRS 3.75(f) f) net exchange differences arising during the period in accordance with IAS 21 The Effects of Changes in Foreign Exchange Rates;

IFRS $3.75(\mathrm{~g}) \quad \mathrm{g}$ ) any other changes in the carrying amount during the period; and

IFRS 3.75(h) h) the gross amount and accumulated impairment losses at the end of the period.

IAS 36, version including amendments issued up to 17 January 2008

IAS 36 Par. 126

IAS 36.126(a)

IAS 36 Par. 129

IAS 36.129(a)
An entity shall disclose, for each class of assets:

the line item(s) of the statement of comprehensive income in which the impairment losses are included

An entity that reports segment information in accordance with IAS 14 Segment Reporting shall disclose the following for each reportable segment based on its primary format (as defined in IAS 14):

the amount of impairment losses recognized in the statement of comprehensive income during the period 
IAS 36 Par. 133 If, in accordance with paragraph 84 of IAS 36, any portion of the goodwill acquired in a business combination during the period has not been allocated to a cash-generating unit (group of units) at the end of the reporting period, the amount of the unallocated goodwill shall be disclosed, together with the reasons why that amount remains unallocated.

IAS 36 Par. 134 An entity shall disclose the information required by (a)-(f) below for each cash-generating unit (group of units) for which the carrying amount of goodwill or intangible assets with indefinite useful lives allocated to that unit (group of units) is significant in comparison with the entity's total carrying amount of goodwill or intangible assets with indefinite useful lives:

IAS 36.134(a) a) the carrying amount of goodwill allocated to the unit (group of units);

IAS 36.134(c) b) the basis on which the unit's (group of units') recoverable amount has been determined (i.e. value in use or fair value less costs to sell);

IAS 36.134(d) c) if the unit's (group of units') recoverable amount is based on value in use:

i) a description of each key assumption on which management has based its cash flow projections for the period covered by the most recent budgets/forecasts;

ii) a description of management's approach to determining the value(s) assigned to each key assumption, whether those value(s) reflect past experience or, if appropriate, are consistent with external sources of information, and, if not, how and why they differ from past experience or external sources of information;

iii) the period over which management has projected cash flows based on financial budgets/forecasts approved by management and, when a period greater than five years is used for a cash-generating unit (group of units), an explanation of why that longer period is justified;

iv) the growth rate used to extrapolate cash flow projections beyond the period covered by the most recent budgets/forecasts, and the justification for using any growth rate that exceeds the long-term average growth rate for the products, industries, or country or countries in which the entity operates, or for the market to which the unit (group of units) is dedicated; and

v) the discount rate(s) applied to the cash flow projections;

IAS 36.134(e) d) if the unit's (group of units') recoverable amount is based on fair value less costs to sell, the methodology used to determine fair value less costs to sell;

IAS 36.134(e) e) if fair value less costs to sell is not determined using an observable market price for the unit (group of units), the following information shall also be disclosed:

i) a description of each key assumption on which management has based its determination of fair value less costs to sell; and

ii) a description of management's approach to determining the value (or values) assigned to each key assumption, whether those values reflect past experience or, if appropriate, are consistent with external sources of information, and, if not, how and why they differ from past experience or external sources of information; and

IAS 36.134(e) f) If fair value less costs to sell is determined using discounted cash flow projections, the following information shall also be disclosed:

i) the period over which management has projected cash flows.

ii) the growth rate used to extrapolate cash flow projections.

iii) the discount rate(s) applied to the cash flow projections.

IAS 36.134(f) $\quad$ g) if a reasonably possible change in a key assumption on which management has based its determination of the unit's (group of units') recoverable amount would cause the unit's (group of units') carrying amount to exceed its recoverable amount:

i) the amount by which the unit's (group of units') recoverable amount exceeds its carrying amount;

ii) the value assigned to the key assumption; and

iii) the amount by which the value assigned to the key assumption must change, after incorporating any consequential effects of that change on the other variables used to measure recoverable amount, in order for the unit's (group of units') recoverable amount to be equal to its carrying amount.

IAS 36 Par. 135 If some or all of the carrying amount of goodwill or intangible assets with indefinite useful lives is allocated across multiple cash-generating units (groups of units), and the amount so allocated to each unit (group of units) is not significant in comparison with the entity's total carrying amount of goodwill or intangible assets with indefinite useful lives, that fact shall be disclosed, together with the aggregate carrying amount of goodwill or intangible assets with indefinite useful lives allocated to those units (groups of units). 
APPENDIX B: Sample companies in alphabetic order

\begin{tabular}{|c|c|c|c|}
\hline NAME & ASE Industry Classification & NAME & ASE Industry Classification \\
\hline ALAPIS S.A. & Health Care & INTERFISH ACQUACUL & Food \& Beverage \\
\hline ATHENS MEDICAL CEN. & Health Care & INTRACOM HOLDINGS & Technology \\
\hline ATHENS WATERSUPPLY & Utilities & INTRALOT S.A. & Travel and Leisure \\
\hline ATTICA PUBLISHING & Media & $\mathrm{J} \& \mathrm{P}$ AVAX SA & Construction and Materials \\
\hline AUDIO VISUAL & Media & KLOUKINAS LAPPAS SA & Construction and Materials \\
\hline AXON HOLDINGS SA & Health Care & KORRES NATURAL & Personal / Household Goods \\
\hline BIOMEDICAL \& ROBOT & Health Care & KREKA SA & Food \& Beverage \\
\hline C. CARDASSILARIS SA & Food \& Beverage & KRETA FARM SA & Food \& Beverage \\
\hline CENTRIC MULTIMEDIA & Personal / Household Goods & LAVIPHARM SA & Health Care \\
\hline COCA-COLA HBC & Food \& Beverage & M. J. MAILLIS S.A. & Industrial Goods \& Services \\
\hline CROWN HELLAS CAN & Industrial Goods \& Services & MARAC ELECTRONICS SA & Technology \\
\hline CYCLON HELLAS SA & Chemicals & MATHIOS SA & Construction and Materials \\
\hline DIAG \& THER CTR & Health Care & METKA SA & Industrial Goods \& Services \\
\hline DIAS AQUACULTURE SA & Food \& Beverage & MOTOR OIL SA & Oil \& Gas \\
\hline DIONIC SA & Industrial Goods \& Services & MYTILINEOS HOLDING & Basic Resources \\
\hline EDRASIS C. PSALLIDAS & Construction and Materials & NIREFS AQUACULTURE & Food \& Beverage \\
\hline EKTER SA & Construction and Materials & NUTRIART S.A. & Food \& Beverage \\
\hline ELBISCO HOLDING & Food \& Beverage & PAPERPACK-TSOUKARID & Industrial Goods \& Services \\
\hline ELGEKA SA & Food \& Beverage & PASAL DEVELOPM & Real Estate \\
\hline ELLAKTOR S.A. & Construction and Materials & PC SYSTEMS SA & Technology \\
\hline ELVE SA & Personal / Household Goods & PEGASUS PUBLISHING & Media \\
\hline EMPORIKOS DESMOS & Personal / Household Goods & PERFORMANCE TECHNOLO & Technology \\
\hline EUROCONSULTANTS SA & Industrial Goods \& Services & PLASTIKA KRITIS SA & Chemicals \\
\hline EURODRIP SA & Chemicals & PROFILE SYSTEMS & Technology \\
\hline EUROMEDICA & Health Care & RIDENCO HOLDING SA & Personal / Household Goods \\
\hline FLEXOPACK SA & Industrial Goods \& Services & S \& B INDUSTRIAL & Basic Resources \\
\hline FOLLI FOLLIE & Retail & SELONDA SA & Food \& Beverage \\
\hline FORTHNET SA & Technology & SFAKIANAKIS SA & Retail \\
\hline FOURLIS SA & Personal / Household Goods & SIDMA SA & Basic Resources \\
\hline FRIGOGLASS S.A. & Industrial Goods \& Services & SPACE HELLAS SA & Technology \\
\hline GR. SARANTIS S.A. & Personal / Household Goods & SPIDER METAL INDUSTR & Industrial Goods \& Services \\
\hline HELLENIC FISHFARMING & Food \& Beverage & THRACE PLASTICS SA & Chemicals \\
\hline HELLENIC PETROLEUM & Oil \& Gas & TITAN CEMENT CO. & Construction and Materials \\
\hline HERACLES G CEMENT & Construction and Materials & UNIBIOS HLDG & Construction and Materials \\
\hline IKTINOS HELLAS SA & Construction and Materials & ALPHA GRISSIN S.A. & Technology \\
\hline IMPERIO ARGO GROUP & Industrial Goods \& Services & IMAKO MEDIA S.A. & Media \\
\hline INFOQUEST SA & Technology & SINGULARLOGIC A.E. & Technology \\
\hline INFORM LYKOS & Industrial Goods \& Services & NAFTEMPORIKI PUBL S.A. & Media \\
\hline
\end{tabular}

